\title{
Ecological Agriculture. Integrating Low Input, High Productive Farming with Wildlife Conservation. Results from the Experimental Farm La Combe, Drome France
}

\author{
Marthe Kiley-Worthington \\ Centre d'Eco-Etho Recherche et Education, La Combe, France \\ Email: marthekileyworthington@gmail.com
}

Received 6 June 2014; revised 7 July 2014; accepted 8 August 2014

Copyright (C) 2014 by author and Scientific Research Publishing Inc. This work is licensed under the Creative Commons Attribution International License (CC BY). http://creativecommons.org/licenses/by/4.0/

(c) (i) Open Access

\begin{abstract}
Wildlife conservation must be integrated with energy and resource efficient agriculture for the human population to survive. Modern high input energy and resource inefficient agriculture does not address these problems. An efficient food producing system which marries wildlife conservation with resource and energy efficient human food production is needed. This is Ecological Agriculture, modelled on how natural ecosystems work. It is defined as: The establishment and maintenance of a diversified, self-sustaining low input farming system managed to maximize net production without causing large or long term changes to the environment. It must be economically viable, and ethically and aesthetically acceptable [1]. Forty years of research on 4 experimental farms have assessed the practicality of this approach (results previously published). The 5th experimental farm in the mountains of the Pre Alps has completed its 10 years. The results are discussed in relation to the tenets of Ecological Agriculture. The techniques previously developed have allowed the results to fulfil the majority of the demands of efficient ecological agriculture and to produce food for $\mathbf{2 0}$ families from the farm's resources despite the difficult climate, topography and soils. It is shown how energy and resource inefficient the omnivorous animals (poultry and pigs) are, compared to herbivores. The species diversity has increased and the whole farm is a nature reserve. Aesthetic and ethical problems have been addressed with an emphasis on a life of quality for farm animals.
\end{abstract}

\section{Keywords}

Ecological Agriculture, Animal Welfare, Wildlife \& Agriculture 


\section{Introduction}

The weightiest environmental problem for the future is how we are going to support the every growing human population (which has a doubling time, now, of around 40 years) and has grown by over 40 million in the last year [2], WITHOUT destroying the rest of the living world? Without a re-assessment of human population growth, there is probably no solution to environmental degradation, however attitudes and politics can change. The fundamental reason why we have to marry wildlife conservation with more infinitely sustainable food production is because without both, we will not survive, however much we give voice to saving the living world as an accessory to our "civilized life”, for tourism or money making.

In the 1960/70's Modern Agriculture assured us that to feed the growing population, we only needed to increase gross yields. The scientific establishment, (with no concern for the long-term effects), gave Nobel Prizes to those who managed this [3], but many ecologists were rightly sceptical.

In 1960's some of the problems facing High Input industrial Modern Agriculture were brought to the attention of the general public by 2 popular books: [4] Silent Spring by Rachel Carson (1965) and [5] Animal Machines by Ruth Harrison (1968) \& articles [6]. As a result, the organic agriculture movements were established (e.g. Biodynamic agriculture, followers of Steiner [7], Eve Balfour [8] \& the Soil Association in the UK, Nature et Progrès in France, \& Ecological Agriculture [9]. The euphemism of Organic Agriculture: "Muck and Magic" was born. Forty-five years later, Organic Agriculture has become mainstream in some areas [10]. But as Woodward [11] points out, it also has been absorbed into the consumer system. Unless clarification of what it really has to offer is outlined, and the emphasis on economic gains is changed, it cannot be a solution to the crushing environmental problems that face the planet.

The most important problem of Modern High Input Agriculture is predominantly ignorance of how living systems work accompanied by the belief that humans can better this. This arises because of:

1) A lack of understanding of the fundamental role decomposers play in maintaining living systems (Figure 1).

2) The substitution of chemicals for a) decomposers, and b) weed and pest control, c) nutrients. These cause a multitude of problems: biological, ethical, social, economic and aesthetic (Figures 2-5). This leads to what is called “an unhealthy environment” [7].

3) The cultural basis of Christianity emphasizes the superiority of humans; the only beings with a soul. The rest of the living system's purpose, they maintain, is to serve human needs.

The goals of an infinitely sustainable efficient, food production system have been defined [1] [9]. The techniques of how this can be achieved in practice have been our concern over the last 40 years.

The aim was to test if modelling agriculture on the way natural ecosystems operate would be a possible solution since they have evolved over millions of years.

This is called Ecological Agriculture, and is defined as:

The establishment and maintenance of a diversified, self-sustaining low input farming system managed to maximize net production without causing large or long term changes to the environment. It must be economically viable, and ethically and aesthetically acceptable [1] [9].

To achieve these aims, 8 principles of Ecological Agriculture were drawn up (Figure 3).

In 1974 at a meeting of the British Ecological Society [12] it was general agreement that these tenets made ecological sense, but few ecologists believed that it could work in practice, or would produce enough food to feed more people.

Perhaps foolishly, in retrospect, I took up the challenge to test whether in practice a farm conforming to the majority of these tenets could operate, and to uncover its major strengths and weaknesses.

All the finance for the research had to come from the farms themselves and activities related to them in order to demonstrate economic viability. Consequently, this experimental project which has involved the development of 5 different farms over 40 years is one of the few research projects that had to been self-financing.

A brief review of the different experimental farms follows.

Farm 1. Milton Court Farm. Sussex, England. (1972-83)

The priorities on this the first farm were:

1) To achieve a self-sustaining system,

2) Calculate the net production.

3) Research HOW farm animals could be kept and raised economically without causing them to suffer. 


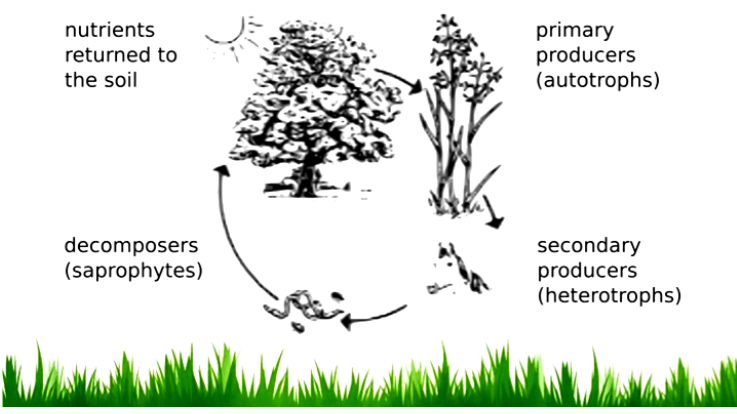

Figure 1. The way in which living systems are self-sustaining (from (1)).

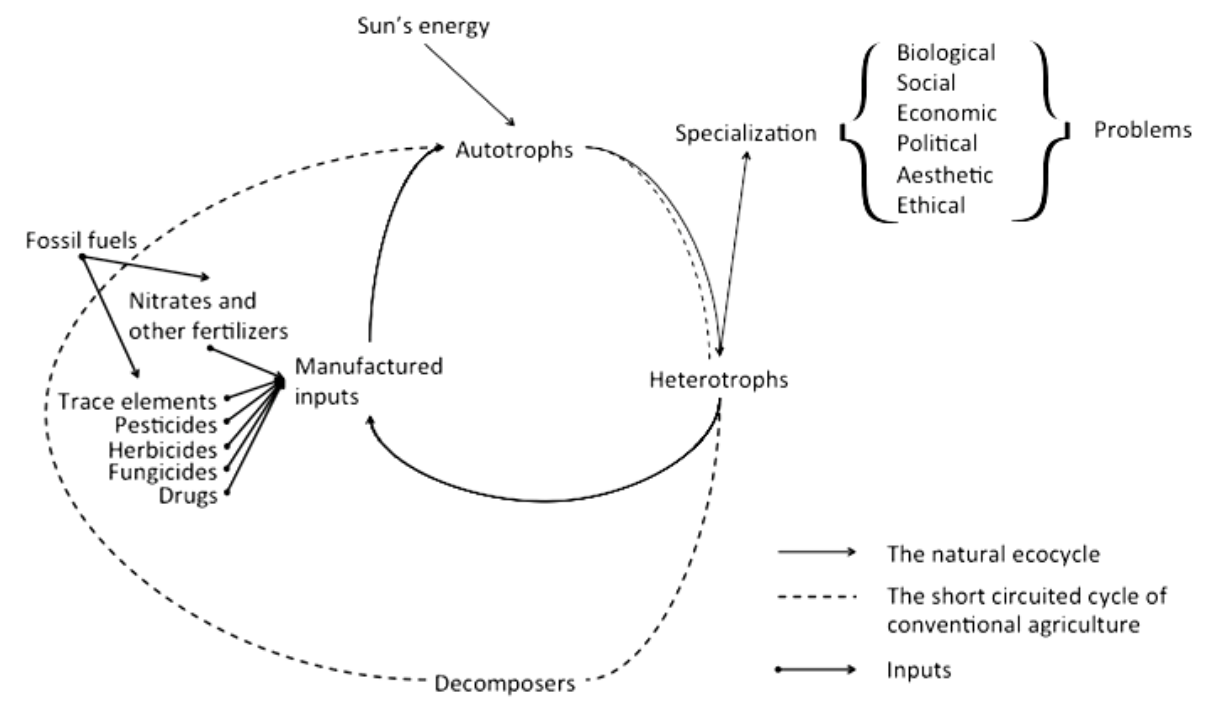

Figure 2. The problems of Modern Agriculture (from 6).

The tenets of Ecological Agriculture

\begin{tabular}{|c|c|}
\hline (adapted from Kiley-Worthington 1993) & \\
\hline - The farm must be self sustaining & - La ferme doit etre auto-suffisante \\
\hline - The farm must be diversified & - La ferme doit etre diversifiee \\
\hline $\begin{array}{l}\text { - The net yield per unit area must be } \\
\text { high }\end{array}$ & $\begin{array}{l}\text { - Le rendement net par unité de surface } \\
\text { doit être élevée }\end{array}$ \\
\hline $\begin{array}{l}\text { The farm should be economically } \\
\text { viable }\end{array}$ & $\begin{array}{l}\text { - La ferme doit être économiquement } \\
\text { viable }\end{array}$ \\
\hline $\begin{array}{l}\text { - The farm processes most of it's } \\
\text { products }\end{array}$ & - Transformer la plupart de ses produits \\
\hline - The overall species diversity \& & $\begin{array}{l}\text { La diversite et le nombre des especes } \\
\text { globale sont augmentés }\end{array}$ \\
\hline $\begin{array}{l}\text { numbers are increased } \\
\text { The whole farm is a nature reserve }\end{array}$ & $\begin{array}{l}\text { - L'ensemble de l'exploitation est une } \\
\text { réserve naturelle }\end{array}$ \\
\hline - The farm must be ethically acceptable & - La ferme doit être éthiquement \\
\hline $\begin{array}{l}\text { The farm must be aesthetically } \\
\text { pleasing }\end{array}$ & $\begin{array}{l}\text { acceptable } \\
\text { - La ferme doit être esthétique }\end{array}$ \\
\hline $\begin{array}{l}\text { - No long term or irreversible changes } \\
\text { should be made to the landscape }\end{array}$ & $\begin{array}{l}\text { Pas de changements à long terme ou } \\
\text { irréversibles doivent être faits pour le } \\
\text { paysage }\end{array}$ \\
\hline
\end{tabular}

Figure 3. Ecological agricultures principles. 


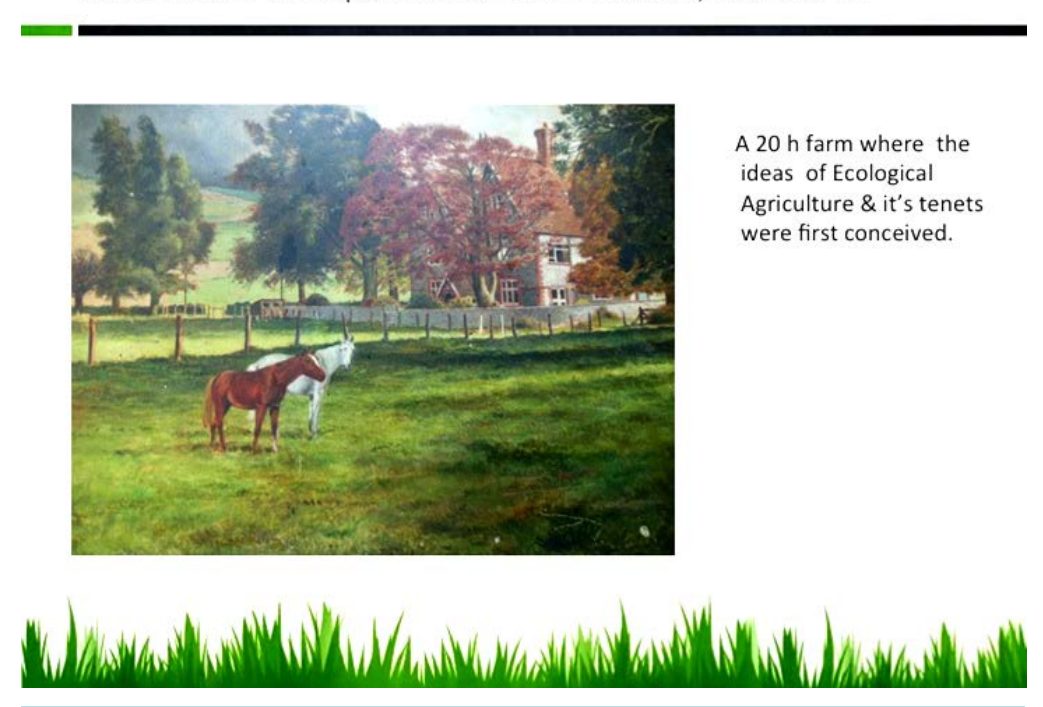

Figure 4. Milton Court, East Sussex, England.

Druimghigha: Experimental Farm, Isle of Mull, Scotland 1983-89

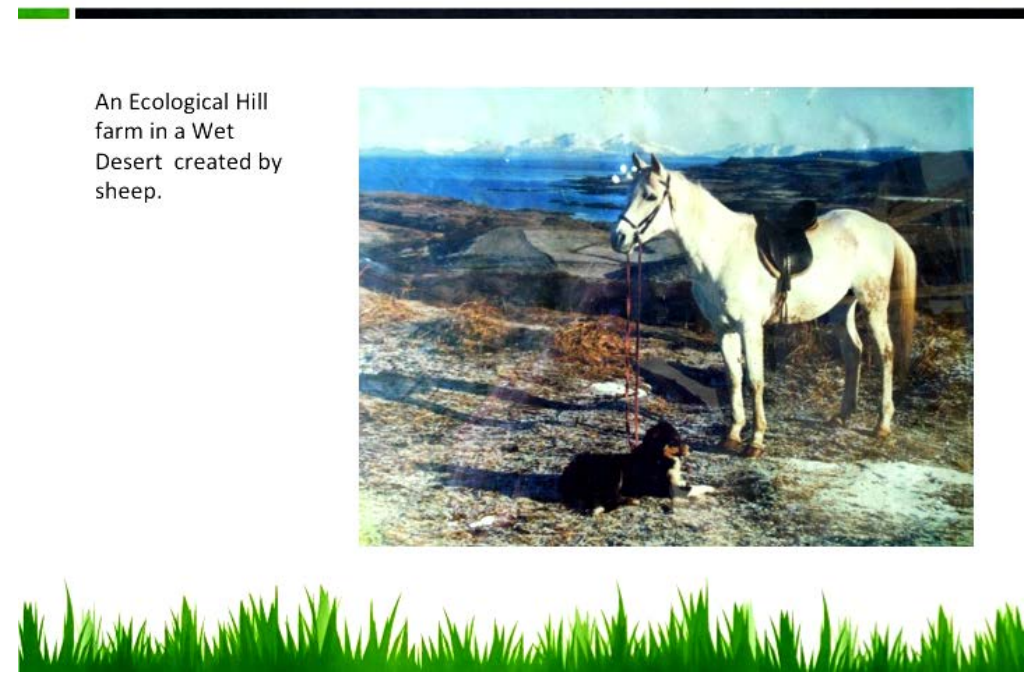

Figure 5. Druimghigha Isle of Mull, Scotland.

At that time it was believed that an "economic" farm could not be run in this way. After 10 years we had more or less achieved these aims (results 1 \& 17). But, the criticism of Ecological Agriculture was that it could be relevant in a rich countries with a good agricultural infrastructure, reasonable climate, soils, transport and markets, but it would be irrelevant in "undeveloped" countries where food problems were common and population growth high. Even today it continues to be argued that the growing human population can only be fed by high input Modern Agriculture where food is transported to consumers, even if this is as Food Aid (e.g. [13]).

To test this, the next farm needed to be in a "developing" area with poor climate and soils, little infrastructure, poor transport and few markets. We bought a 250 ha hill farm on the Isle of Mull in the Hebrides: a "wet desert” and "undeveloped area”, and moved there in 1983 with peacocks, poultry, cattle, horses, pianos, books and students.

Farm 2. Druimghigha Isle of Mull. Hebrides Scotland (1983-89)

This farm had little agricultural infrastructure, no cultivated land, few fences. There were no markets on the island \& poor communication with the outside world. Almost no cereals, fruit, vegetables or milk were produced on the island. Sheep and cattle ate any regenerating trees, and farmers were paid to have larger herds in order to 
be economically viable.

It is a remote, wet, farm with a very acid soil on a beautiful island with many similar characteristics to marginal areas in 3rd world countries; but it is a wet desert created by man and his sheep. We had to develop the soil and install drainage on cultivatable areas. After 8 years, we produced wheat, barley and oats, and had improved the grass production by $3 \times$ on around $20 \mathrm{ha}$. We erected around $18 \mathrm{~km}$ of fencing, planted fruit trees \& vegetables, build farm buildings and protected the last remaining natural forests, while encouraging all types of wildlife.

In 1989 we had figures to show that what we had set out to do could be achieved in this difficult area ((1) chapter $6 \&$ [14]). The restraints were not biological, but social: the beliefs of the population concerning what could grown.

The next question to examine was the widely held belief that human interests (or "rights"), even trivial ones, should always trump life threatening interests of other of species [15]. This results in an increasing rate of extinction of species (now at around one per day) [16].

Should domestic species suffer in order to feed humans and should wild life be restricted to "nature reserves" that is areas that, apparently, cannot not produce human food?

It might be possible for the interests of both wild and domestic animals and plants, as well as humans, to be catered for on one farm. Could the whole farm (rather than areas of it) be a nature reserve and managed to increase species diversity and numbers, while remaining a highly efficient (net productive) food producing area where all sentient beings have a life of quality?

Farm 3. Little Ash Eco-Farm. Dartmoor, Devon. S.W. England (1989-2003)

A 30 hect of grass and woodland in the Dartmoor National Park in Devon UK was bought to test this hypothesis.

Since there were no buildings, we had the opportunity to design and build a multi-species barn, designed to increase animal welfare; reduce labour and energy needs; and allow a comfortable living space for humans. We were to alter the living environment as little as possible and hide the building (no trees were to be cut down for its erection, and the fences to be hidden or replaced by Ha Ha's, hedges and the planting of hard wood forests). Both the wildlife and the aesthetics were to be important considerations. Climbing plants were planted around and inside the building, natural home produced building materials were used wherever possible, and the design of the gardens and orchards was informal, often controlled by chance.

Eventually we constructed a traditional eco-house from materials off the farm and recycled material (mud, straw and wood) which had to conform to the strict UK building regulations. It was cheap to build and was aesthetically pleasing and we won environmental awards for both the house and the farm building (Figure 6) in the National Park.

Renewable energy was supplied by one of the first windmills in the area. Water heated from solar panels (Figure 6 bottom right porch roof). We supplied our own water from a spring on the farm which was pumped by a ram pump (a pump that uses the energy of the flowing water to pump $10 \%$ of the water) to storage tanks hidden at the top of the farm, from which, the water flowed by gravity to the building. The energy budgets were calculated as accurately as possible which involved some guesstimates. Although not as good as a natural ecosystem, (where energy produced has to balance energy used to remain a stable ecosystem), the energy budgets were better than other non-organic and organic farms. Thus, more energy was produce than was brought in from outside the farm: 1 calorie produced on the farm for 0.55 bought in (Table 1). But, if other hidden energy uses such as the construction of the machinery, transport to the farm and so on, were allowed for, this figure is probably more like 1:0.75 produced to used. This is better than other farms where the most "efficient" calculations for animal products are $7 \mathrm{cal}$ use for $1 \mathrm{cal}$ produced [17].

With the addition of producing renewable energy from wind and the resident animals and people, it is clear that it is possible to balance the energy budgets at least in some areas with good climates and soils. It is also important to note that the most important exports from the farm were animal products (milk, fibre \& meat) this indicates that the production of animal products, particularly from herbivores, do not have to be energy consuming if raised on self sustaining farms (in food/fodder and energy).

The whole farm became a nature reserve. Bird numbers and species increased (RSPB report 1998), 1 ha of mixed woodland was planted, as well as fruit and vegetables 0.5 ha providing more food for the indigenous fauna as well as those introduced. This experiment ran for 12-years (more results 1 Chapters 7, 8, 9 \& [17]).

The next project was to address the loss of species in the high mountains of Europe. This is generally because of: 
Little Ash: Experimental Farm in Devon. SW England.

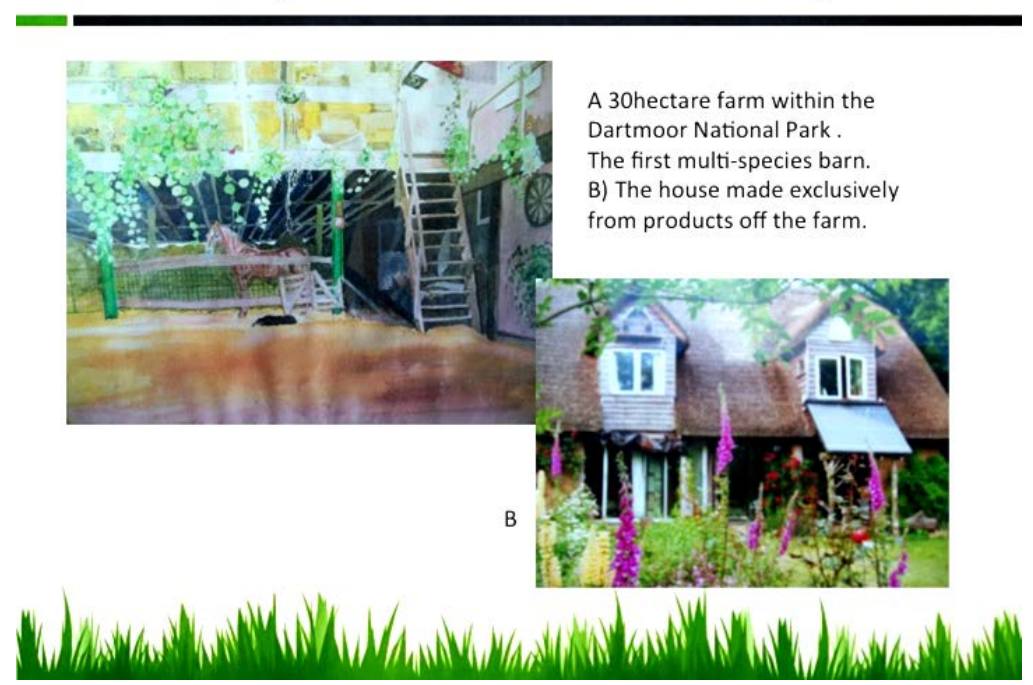

Figure 6. The Ecological farm building and house on the ecological farm in Devon, UK.

Table 1. Energy budgets. Little Ash Eco-Farm (from 1 \& 17).

\section{Energy produced on the farm.}

$3 \mathrm{kw}$ windmill for electricity, solar water heating \& horse and human power (fed from the farm).

Total annual energy production (windmill, solar, milk, animals, wood, vegetables, cereals etc.) = 279,097 MJ estimate.

Imported energy.

Running tractor, transport \& machinery.

Diesel \& transport $=154,128$ MJ.

Net energy production 279,097 $-154128=124,969 \mathrm{MJ}$ off 33.3 hectares.

Net energy production/hectare $=\mathbf{3 7 5 2 . 8} \mathbf{M J}$.

1 produced to 0.55 used.

Other hidden energy used suggests around 1 produced to 0.75 used, likely to be more accurate.

1) Loss of habitat as a result of development of tourism (skiing walking etc.), roads, houses and so on.

2) Reduced transhumance (summer grazing of domestic animals) which formally were taken into the high montane grasslands.

The question addressed here was: could a mountain ecological farm with difficult topography, soils and climate be a successful productive ecological farm conforming to the tenets of Ecological Agriculture (Figure 3), including economic viability? Could small numbers of tourists be welcomed and domestic \& wild animals have a life of quality throughout the year on a mountain farm? At the same time, the whole area was to be a nature reserve with species diversity and numbers to be increased.

The mountain of La Drome (in the Rhone Alps, France) was chosen. We arrived with the snow in December 2003. No one had lived on the farm for 60 years (and then only during the summer), and little human food had been produced from the farm during its history.

Farm 4. La Combe. Bezaudun sur Bine, Drome. France. This is a 175 ha isolated precipitous mountain farm (650 - $1200 \mathrm{~m}$ altitude).

To assess its efficient productivity, it was decided to test whether or not this farm could - following the tenets and techniques discovered for Ecological Agriculture, produce from its own resources, enough food to feed 20 families ( 2 adults \& 2 children each family) while the whole farm is also a nature reserve.

Could the farm also be economic but at the same time be a "multi species community"? This is where every species interests are considered equally, thus human interests do not trump those of other species without careful con- 
sideration for the quality of life of the individuals and other species in the ecological community [12] [19] [20].

This farm has a difficult climate with cold long winters (frosts November to May, temperature $-30^{\circ} \mathrm{C}$ occasionally) and hot dry summers (July-October with temperatures up to $40^{\circ} \mathrm{C}$ sometimes). There is frequently no rain between end of June and September. It is alkaline (pH 8 - 9), limestone bedrock with clay and stones and very little humus or top soil.

For some centuries it was traditionally grazed with sheep, goats and cattle during the summer. There is still some evidence of erosion as a result of over grazing over a century ago. The human population has declined in the commune over the last century (from 2000 in 1900 to 95 in 2014) as a result of migration to the cities.

This farm was abandoned in 1950 and over 50 years was heavily colonized by indigenous bush (broom, rose, juniper, \& box). Pockets of the climax vegetation: beach, with a scattering of pine, oak, European myrtle, ash and willow in wetter areas remain. From 1950-2003 the farm was used for shooting and occasional horse grazing. At the beginning of the experiment in 2003, there was approximately 1 ha of dry open grassland (Figure 7).

\section{Results}

The results of the 10-year experiment at La Combe are discussed in relation to the tenets of Ecological Agriculture (Figure 3).

1) Self sustainability in energy, water, food and fodder

a) Energy

Human and horse energy were used where they were the most effective. For example it is often more efficient to milk 1 - 3 cows by hand rather than with a milking machine. Similarly the planting, weeding and harvesting of vegetables by horse and hand allows greater production per square meter than using a tractor (Figure 8).

The most effective way to capture renewable energy in this area is solar since the hours of sunlight is approximately 2200/year. In 201063 sqm of solar panels were fitted. A 6 kw windmill was installed in 2005. Winds blow erratically but can be @ $100 \mathrm{k} / \mathrm{hr}$. There is also the possibility of hydro-electric production from the recently built dam, but this is in the planning stage.

The following Table 2 shows the approximate annual energy production and consumption from the farm for the 10th year of operation.

The energy produced does not quite balance that consumed, but the energy budget is considerably better than most other farms in the area.

\section{b) Water}

Water is available from 7 springs, 3 of which run throughout the year, and a small stream which rises above the farm and runs all year. There is little surface water since it is on limestone. Care has to be exercised to ensure there is sufficient water for the human occupants, animals and particularly the vegetable and fruit garden irrigation in the summer. There is insufficient water for any field irrigation.

A simple, recycling dry toilet has been built to economize on human water use and water from the houses is recycled through a reed bed (Figure 9 left).

A dam was constructed in 2010-12 (0.5 h up to $3 \mathrm{~m}$ deep, Figure 10 right) to store water, but also to have a fresh water habitat to attract wild fauna and flora and grow indigenous fish. It adds considerably to the aesthetic attraction of the farm (Figure 9 right).

The results over the last 10 years indicate that there is enough water to provide sufficient irrigation for growth to feed 20 families which includes the irrigation of approximately 1 ha, but if rainfall falls further, it will be difficult to grow sufficient cereals for humans.

c) Human food production (estimate for 20 families)

Figure 10 show that it is possible to provide enough vegetables, fruit, nuts, milk products, oats and wheat from this Ecological farm for 20 families. It is however more difficult to supply sufficient poultry, pigs and their products (eggs \& meat) Both these omnivorous species compete with humans for food since they need considerable quantities of cereals and proteins, rather than converting cellulose from grasses and forage.

d) Livestock fodder production (for 20 families)

Figure 11 shows the numbers of herbivores and how they are fed. Although all the forage is not at present produced, particularly straw, it is possible that as the fertility of the cultivated areas increases over the next 5 years this will be possible. The amount of bought in straw, the largest import, will be reduced as the humus levels rise and yields increase. It is clear that the improvement and management of grassland is a key aspect for 
La Combe: Experimental Farm, La Drôme, France

Integrating nature conservation and increased food production.

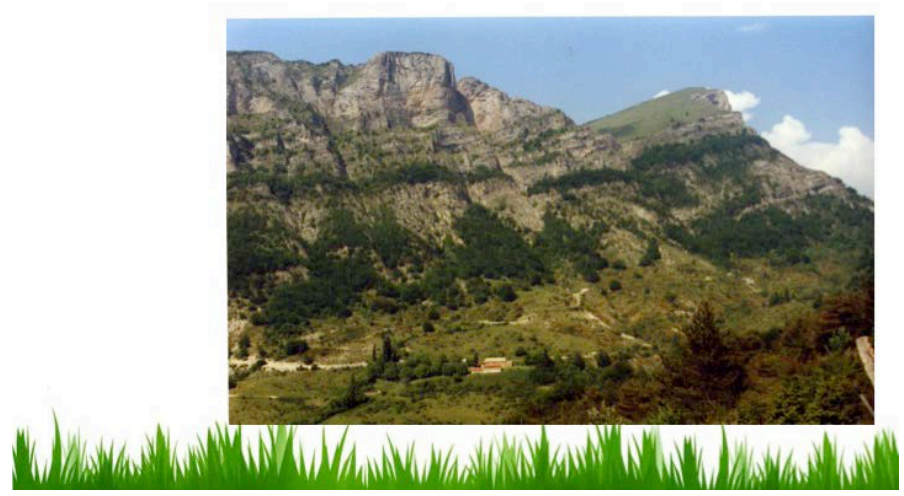

Figure 7. La Combe, Rhone Alp, France.

Energy. Human, Horse, Wind Solar \& Water.

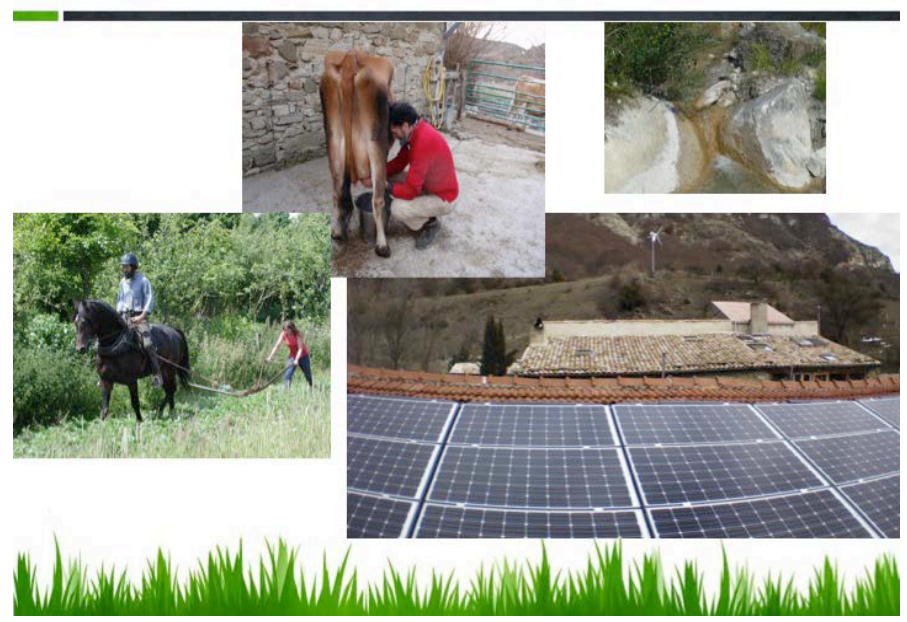

Figure 8. Energy production.

Water care, conservation, drainage \& watering

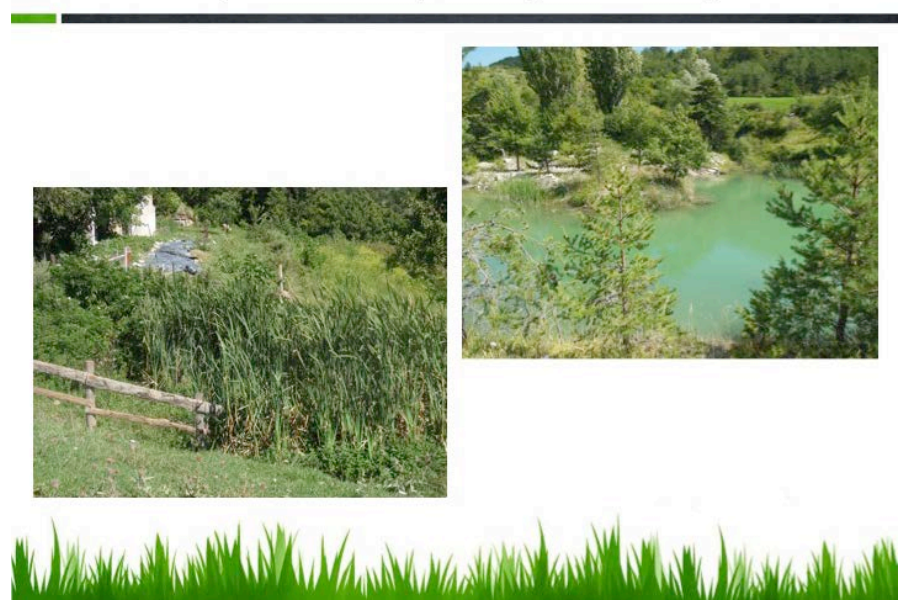

Figure 9. A reed bad for recycling water, and a small dam for its conservation. 
Self-Sufficient Food produced 20 families possible?

\begin{tabular}{|c|c|c|c|c|c|c|}
\hline Food & $\begin{array}{l}\text { Need for } 1 \\
\text { family }\end{array}$ & $\begin{array}{l}\text { Need } 20 \\
\text { families/ } \\
\text { year }\end{array}$ & $\begin{array}{l}\text { amount } \\
\text { produced }\end{array}$ & Difference & Require: & Possible? \\
\hline Vegetables & $5 \mathrm{~kg} /$ week & $5,200 \mathrm{~kg}$ & $3,774 \mathrm{~kg}$ & 1,425 & $<285 \mathrm{~m} 2$ & $\begin{array}{l}\text { Yes +1 } \\
\text { worker }\end{array}$ \\
\hline Fruit & $30 \mathrm{~kg} /$ year & $600 \mathrm{~kg}$ & $\begin{array}{l}600 \mathrm{~kg} \\
\text { (good yr) }\end{array}$ & 0 & $\begin{array}{l}<\text { as trees } \\
\text { mature }\end{array}$ & Yes, + \\
\hline Nuts & $3 \mathrm{~kg} /$ year & $\begin{array}{l}36 \mathrm{~kg} \\
\text { (husked) }\end{array}$ & $\begin{array}{l}24 \mathrm{~kg} \text { ( husk } \\
\text { ed) }\end{array}$ & $12 \mathrm{~kg}$ & $\begin{array}{l}<\operatorname{cob} \& \\
\text { chestnut }\end{array}$ & Yes \\
\hline Potatoes & $2 \mathrm{~kg} /$ week & $2,080 \mathrm{~kg}$ & $30 \mathrm{~kg}$ & $2,050 \mathrm{~kg}$ & $1000 \mathrm{~m} 2$ & Yes \\
\hline Wheat & $4 \mathrm{~kg} /$ week & $4,160 \mathrm{~kg}$ & $1,000 \mathrm{~kg}$ & $3,160 \mathrm{~kg}$ & $\begin{array}{l}<2 \text { hec \& }< \\
\text { yield }\end{array}$ & $\begin{array}{l}\text { ?possible } \\
\text { <yield }\end{array}$ \\
\hline Oats & $1 \mathrm{~kg} /$ week & $1,040 \mathrm{~kg}$ & $50 \mathrm{~kg}$ & $1,010 \mathrm{~kg}$ & $<1 / 2$ hec & possible \\
\hline Milk products & $1.51 /$ day & $10,800 \mathrm{l}$ & $\begin{array}{l}2,700 \mathrm{l} \\
1 \mathrm{cow}\end{array}$ & 7,1001 & $\begin{array}{l}<\text { by } 3 \\
\text { cows }\end{array}$ & $\begin{array}{l}\text { Yes +1 } \\
\text { worker }\end{array}$ \\
\hline $\begin{array}{l}\text { Poultry \& Pigs } \\
\text { (eggs \& meat) }\end{array}$ & $\begin{array}{l}\text { 5hens, } \\
1 \text { porker/ } \\
\text { year }\end{array}$ & $\begin{array}{l}100 \text { hens } \\
2 \text { sows \& } \\
\text { piglets }\end{array}$ & $\begin{array}{l}10 \text { hens } \\
0\end{array}$ & $\begin{array}{l}90 \text { hens } \\
?\end{array}$ & $\begin{array}{l}<\text { by } 90 \\
?\end{array}$ & $\begin{array}{l}\text { ? Feed } \\
\text { problem }\end{array}$ \\
\hline
\end{tabular}

Figure 10. The production of different foods required and produced to feed 20 families.

\section{Livestock and their food.}

\begin{tabular}{|c|c|c|c|c|c|c|}
\hline Food & $\begin{array}{l}\text { Numbers/ } \\
\text { to produce } \\
\text { food } 20 \\
\text { families }\end{array}$ & $\begin{array}{l}\text { Numbers } \\
\text { present }\end{array}$ & $\begin{array}{l}\text { Amount } \\
\text { produce } \\
\text { d.kg }\end{array}$ & $\begin{array}{l}\text { Amount } \\
\text { needed } \\
\mathrm{kg}\end{array}$ & $\begin{array}{l}\text { Difference } \\
\text { Between }\end{array}$ & $\begin{array}{l}\text { Likely } \\
\text { changes } \\
\text { in next } \\
\text { years. }\end{array}$ \\
\hline Horse & 2 & 7 & 1 foal & - & 0 & $\begin{array}{l}\text { Reduce } \\
\text { number }\end{array}$ \\
\hline Cattle & $10+$ calves & $\begin{array}{l}5 \\
\text { finished }\end{array}$ & 2,000 & 2,000 & 0 & $\begin{array}{l}\text { Increase } \\
\text { dairy }\end{array}$ \\
\hline sheep & 20ewes & 25lambs & 400 & 500 & $-100 \mathrm{~kg}$ & $\begin{array}{l}< \\
\text { lambing } \\
\%\end{array}$ \\
\hline Straw & & & 1ton & 15 tons & - 14tons & Buy $1 / 2$ \\
\hline $\begin{array}{l}\text { Hay \& } \\
\text { silage }\end{array}$ & & & 11 tons & 13 tons & - 2tons & will < \\
\hline Cereals & & & 1. tons & 6.5 tons & -5.5.tons & will $<$ \\
\hline
\end{tabular}

Figure 11. The numbers of livestock and the amount of food produced and required for them.

feeding the herbivores \& maintaining species diversity. It can be considered crucial for a self sustaining system. (see h below).

The production of hay and silage increased over the 10 year period and with a continuation of this type of management, without increasing the cultivated areas by more than 3 ha it is considered that sufficient fodder crops could be produced to feed the growing number of herbivores. The pigs and poultry's needs are however more difficult to meet since more grains would have to be grown.

e) Bush clearing, spreading muck \& fencing

This has been a difficult \& time consuming task but it is now, 10 years on, reaping benefits and the net production is increasing fast (see below). The aim was to spread 1 tonne/ha/year of muck on the cultivated areas, but this has not always been achieved.

f) Increasing soil fertility \& production by increasing humus \& nutrients 
Table 2. Energy produced and consumed on the farm for 2013.

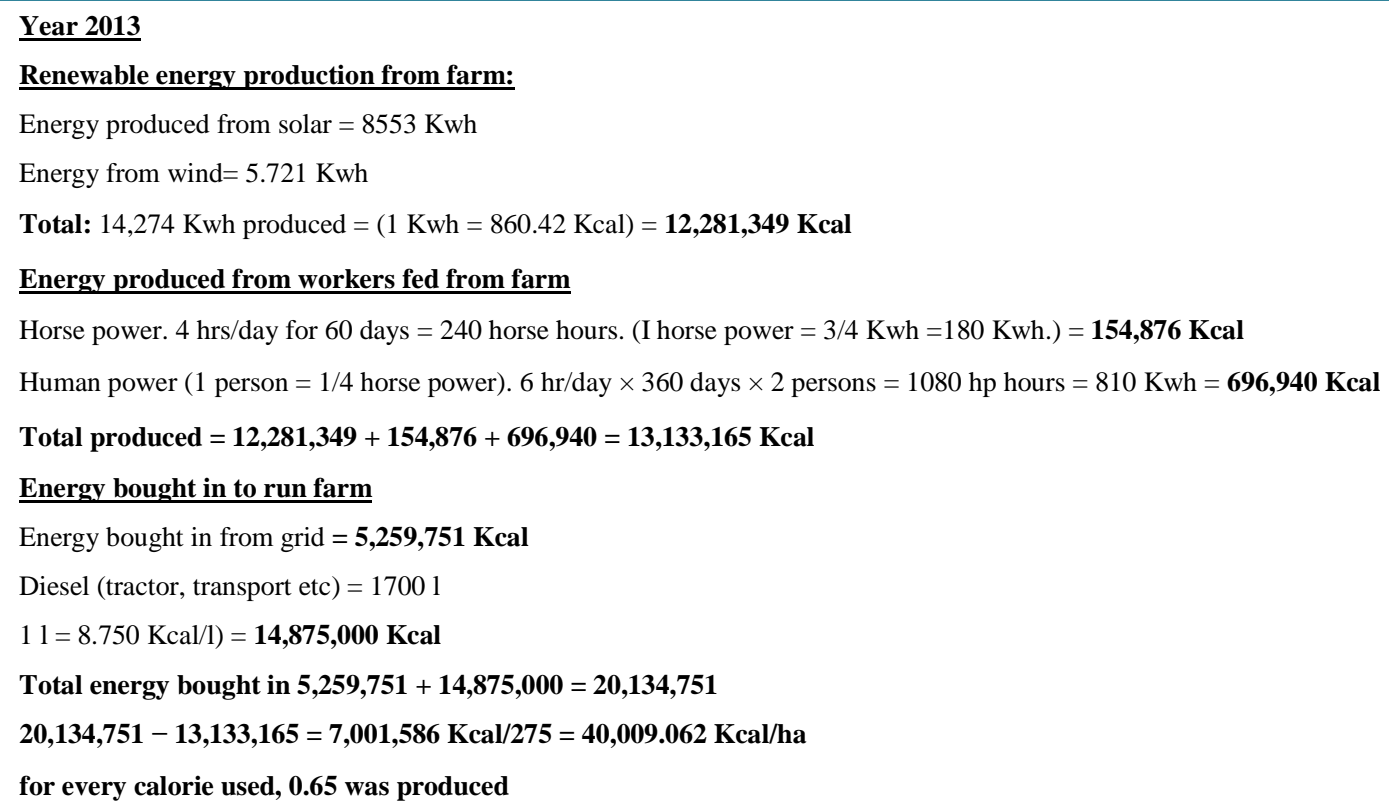

The importance of this to establish a greater fertility was first demonstrated by Howard in India in 1850 [8]. To do this, there is a need for large amounts of waste material of organic origin. There were two options to increase organic material on this farm:

i) The clearing of possibly productive areas in order to cultivate them by cutting the invasive bush. The cut bush could remain to decompose in situ. But, the high lignin content combined with the short period in the year during which decomposers are active in this climate, meant that decomposition is slow. Leaving the cut bush in situ had two other disadvantages:

a) The cut bush was not always in the place which could benefit most from additional humus and consequently required moving.

b) The cleared area could not be ploughed and reseeded until the bush had broken down which meant further delay in soil improvement and production.

c) Burning the cut bush when piled up or in place. This had the effect of leaving nutrient rich areas where the burn had been, but it sacrificed the eventual humus benefit from the decomposed bush.

ii) Buying in generous quantities of straw. Because of these disadvantages, a technique that had previously been employed in other humus low areas was used [14]. This was to keep the livestock on the fields all winter and feed fodder on the fields to be improved. Initially insufficient fodder could be produced, although sufficient shelter was provided by the natural vegetation and topography to allow the livestock (bovines, ovines \& equines) to live without discomfort. The advantages of this system are:

a) The urine and faeces are deposited where the land can benefit directly from the increase nutrients.

b) There is no need for energy to be used in nutrient or humus distribution.

c) It requires less manpower.

The disadvantages are:

a) Since the straw decomposed in situ, there was a delay of 2 - 4 years before the benefits of increase soil fertility were evident.

b) The straw had to be imported and consequently reduces the self-sustainability of the farm.

The same results could have been achieved without the benefit of the bought in straw, but it would have lowered stock numbers and consequently required longer to improve the soil to allow for cultivation. The straw was bought in from local farmers as cereals are grown on the lower ground.

Other products off the farm could also have been used to increase soil nutrients, such as leaves collected from the forests, but this would have meant considerably more labour.

The main sources of farm nutrients was manure from the animals that were stabled at night and bedded on 
straw during the winter, and the decomposed wastes from the human dry toilet (1 to 2 tons/year). The total amount/year was in the region of 16 tons. The decomposed human waste was spread and ploughed in on a field which would then grow animal fodder. This was to negate any possible disease transfer.

The stable muck is spread in the early spring in order to reduce nutrient loss through leaching with the snow and rain in the winter (Figure 12).

The area requiring the most nutrients was the vegetable garden and fruit ( 3 ton/ha) applied annually.

\section{g) Cultivation techniques employed}

\section{i) Ploughing}

Relatively shallow ploughing of the cleared land at the rate of an average of $1.5 \mathrm{ha} /$ year of new ground was achieved by a 4 wheel drive 2nd hand John Deere 2250 tractor. The first plough encountered a great many roots and rocks some of which had to be removed which made it very slow. To avoid the tractor rolling, or the plough snapping it had to be done with care.

ii) Stone picking

Each ploughing brings many stones to the surface. Stone picking by hand will have to continue for another 20 years.

iii) Post ploughing soil preparation

After ploughing, a spring tine harrow was drawn 1 - 4 times over the newly ploughed land. Thereafter a spike harrow (1 - 4 passes) would prepare it finally for drilling. Care had to be taken not to compact the soil in wet weather. When wet, the final preparation was done with horses which was slower and required skilled people to work the horses, but caused less compaction.

iv) Drilling

The cereals were usually drilled with a tractor. Sometimes the grasses and clovers were hand broadcast and then harrowed by horse, particularly when the land was wet or in small difficult areas. The first drilling was usually improved grasses, clovers and lucerne mixes.

v) Harvests

The second ploughing and seeding on some areas was cereals (wheat and oats for human consumption) but it was not until the 5th year that we attempted to harvest the cereal grains. It was not possible to obtain a contractor to harvest the cereals so we obtained and re-constructed an ancient reaper-binder which was able to work well on the small steep fields. The first harvests of wheat where small ( $1-1.5$ ton/ha), but with the improvements of the soil and techniques, there is every possibility that these harvests will increase. To date thrashing is done by hand, but an old thrashing machine will be more efficient.

The growth after first ploughing was often disappointing, but, after the 2nd or 3rd ploughings the response was much improved. The grasses and clover cover was very slow to establish taking two years rather than one year on the majority of lowland farms. The first year the grass \& clover was grazed quickly with cattle and horses to encourage tillering. Not until the second year was it productive enough to enter the grazing and hay/silage rotation. After year 6 we started to make a little silage (2 tons).

\section{h) Grassland management}

One of the key features of successful diversified farming systems is grassland management [1] \& [18]. To develop an economic farm and a self sustaining system where all the livestock can be fed off the farm, the first priority is to develop productive grassland. Our team had completed many years of research in this area in UK, Kenya, South Africa \& Zimbabwe.

The indigenous grass sward, although rich in species, was neither very palatable nor productive. Although it is important to recreate and conserve some of these montane pastures and use them for summer grazing, (see 2 below), it was also necessary to increase production of some of the land in order to feed the grazing stock throughout the year. Thus, around 15 ha of land was brought into production and used for grass and clover in rotation with cereals. Experimental mixing of grass and nitrogen fixing trefoils (6 grass species, 8 trefoils species sown at a ratio of 1:2: Figure 13) proved productive. The grazing management is done in rotation with two or three species resulting in a tight graze followed by a rest of the pasture to regrow. This is followed by a cut for hay or silage and then another regrowth before a final autumn graze, if sufficient rain. We attempt 2 grazings each area each summer but this has not always been possible.

The hay \& lucerne cuts have averaged around 2.5 ton/ha, which are low, but if this type of management continues, there is every possibility of a considerable increase (further details of this type of intensive grassland management in [1]). 


\section{A) Cleared bush, B) spreading muck, C) fencing}

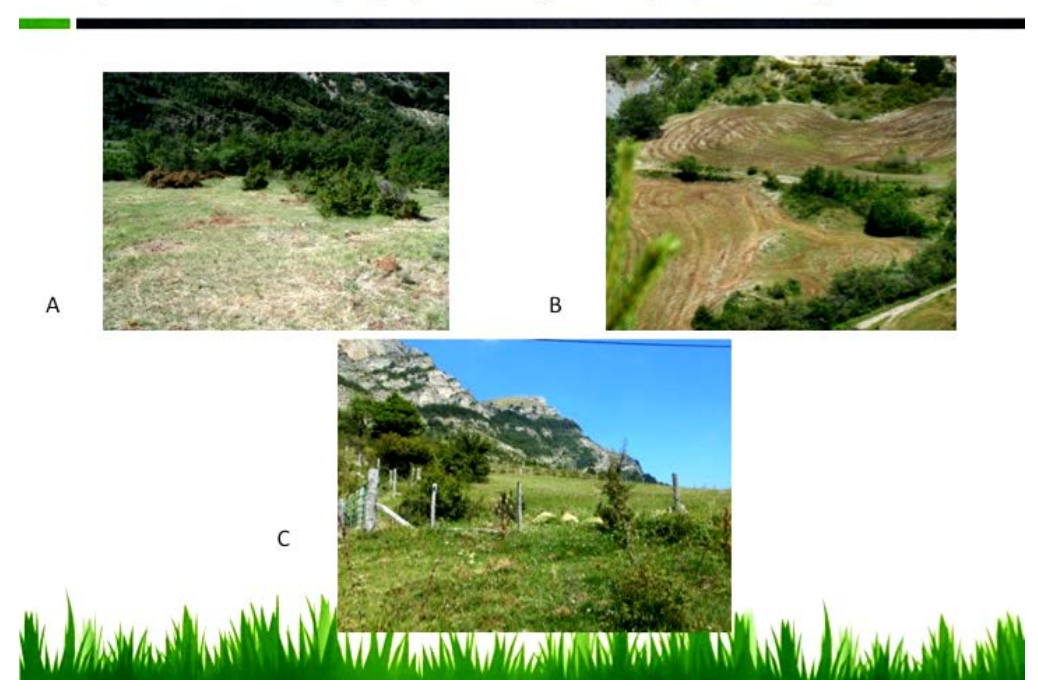

Figure 12. Changes to the land for cultivation and increased net production.

\section{Improved pastures}

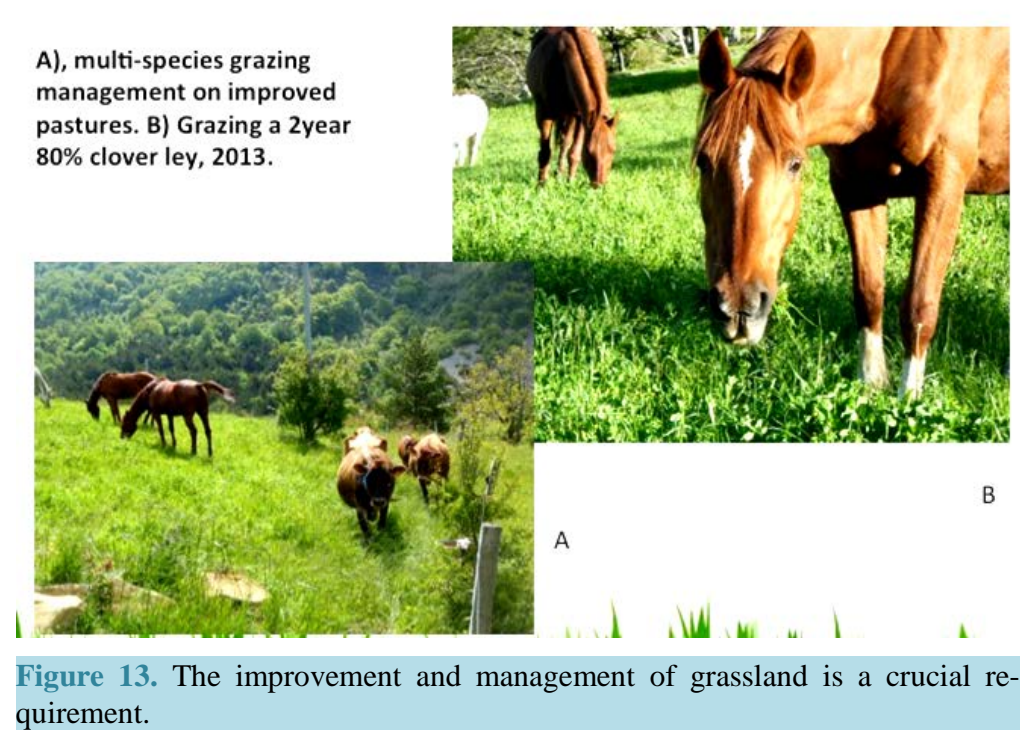

\section{i) Vegetables, market garden $\&$ fruit}

The vegetable garden was created out of a sloping bush covered area south of the buildings (Figure 14). This area was chosen because:

a) it was close to the house to enable it to be easily overseen \& protected.

b) water was available.

c) it was growing bush and considered to have some soil that could be improved.

d) it was sunny and south facing for early production.

e) it was possible to construct long rows to work easily with the horses.

The vegetable site proved not to be well sheltered, despite planting of shelter belts; it remains wind blown. We have constructed 5 terraces which makes it easier to work. Although initially there was little but clay, the soil has now begun to become loam in some areas by grace of the applications of composted muck (around 3 tons annually). The market garden is managed to maximize production per square meter rather than have space between rows, we plant 3 rows very close to discourage weeds separated by a wider track for inter-row weeding 


\section{The creation of a market garden with 5 terraces}

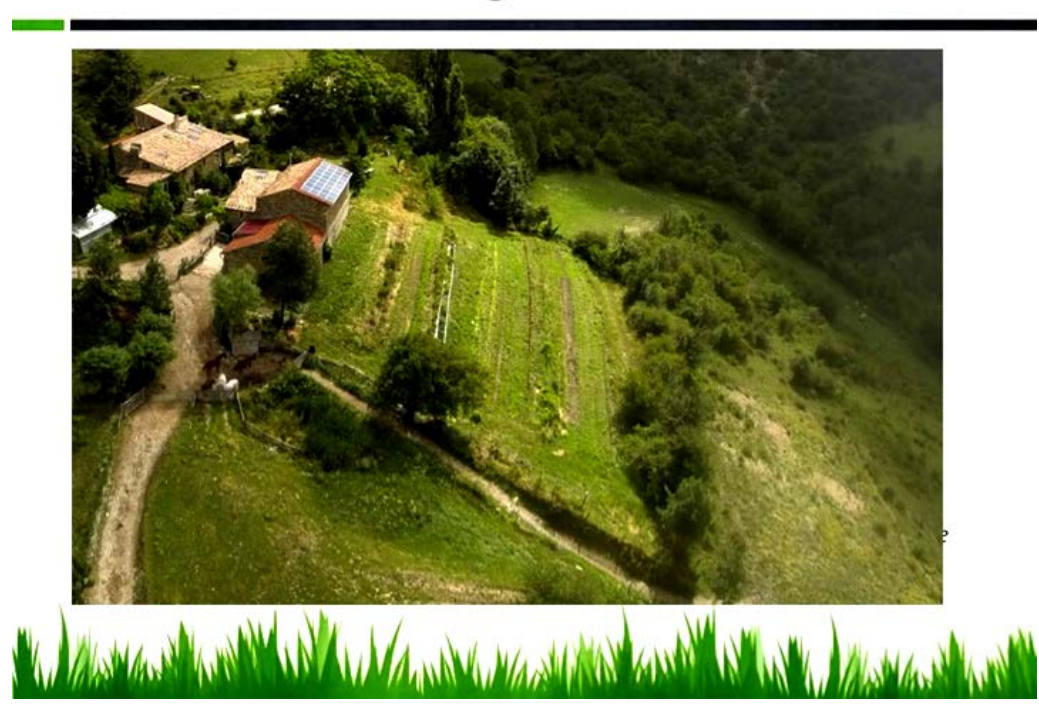

Figure 14. The house \& buildings with solar panels, and 5 terrace market garden.

with the horse cultivator. All the preparation of the soil, planting, weeding etc is done by horse or human hand, but only 5 hours/week are spent in the garden. The production per meter squared for the terraces averages 3.14 $\mathrm{kg}$. Drip feed irrigation proved to be ineffective due to blockage of the pipes with calcium carbonate from the water, so an infra-structure of overhead pipes and sprinklers has been installed.

Strawberries proved to be particularly productive and economic. A commercial self-pick crop now covers one terrace and any not sold fresh are sold as preserves. Black currants and herbs such as rosemary also grown well.

The main shortage in food to date is vegetable oil. One year we grew a terrace of sunflowers and established that with correct harvesting, these could supply sufficient oil if grown on a field scale. Other short falls are coffee although coffee and tea bushes have been grown in the green house. Once the temperatures are better controlled in the double and triple glazed green houses, (heated by solar and wind energy off the farm), some olives and citrus fruit could be grown for the 20 families but these species cannot winter outside.

Around 80 stone fruit trees have been planted around the house. These including 6 varieties of apples, 2 of pears, 2 of apricots, 1 cherry, 4 plumes, 3 crab apples, 1 quince, mulberry etc. All the trees are now fruiting. With care the production should increase (see Figure 10). The added advantage of stone fruit trees is that palatable quick growing grasses and clovers can grow beneath and be grazed at appropriate time of year by sheep and horses, although cattle tend to eat the trees. Thus a double crop off the land can be achieved when suitably managed.

Approximately 15 mature walnut trees were inherited with the farm and continue to produce. Around another 100 walnuts have been planted. The walnuts can be sold entire, eaten on the farm or pressed for oil. We have also planted around 8 almonds now producing small crops.

Some cob nuts have also been planted, although they find the alkalinity difficult. We also have an area on the farm of sandstone where some 20 chestnuts of various ages have established themselves.

Although each year differs, provided a variety of fruit and vegetables which flower and fruit at different timesof year, the area has potential for expansion in fruit and vegetables.

Lavender "fine" (wild lavender) is an ingenious crop here and the plan is to plant a hectare of this as a cash crop on a difficult south facing slope which has not responded well to grasses.

\section{2) Species Diversify}

\section{a) Domestic and introduced species on the farm}

The farm produces sufficient vegetables to feed 20 families, from around 35 major species, and it grows 15 types of fruit. It produces cereals wheat \& naked oats although not sufficient to date to feed 20 human families or all the resident livestock.

There are approximately 40 species of trees on the farm, some indigenous, some introduced. The forests are used for firewood, building, artisanal activities, wildlife and for aesthetic value. There is an extensive shrubbery 
and flower garden containing approximately 40 introduced species and providing food, shelter, nesting possibilities for indigenous fauna. There are 9 species of domestic mammals (including humans) on the farm (Table 3).

The ornamental gardens include shrubberies, herbaceous borders, ponds, lawns and open woodland. The gardens have been developed to retain informality of the nature world but at the same time useful and aesthetically pleasing: to lighten the spirits of visitors and workers by being a beautiful informal natural environment. They also have functions for humans and their animals, for example fruit trees grazed underneath by sheep, reed bed for water purification \& ducks, and lawns grazed by horses.

\section{3) Conservation of the natural world \& wild species diversity}

In 2010 the whole farm was declared a nature reserve (Association ASPAS). During the 10 years the experiment has been running. The wild fauna and flora has been monitored to assess whether the individual species are increasing or declining in numbers.

One large herbivore that is in decline is the chamois on the farm. The reason for this is predominantly that hunting has been allowed on the adjacent property which is now owned by the government. The number of chamois that are permitted to be shot on this is greater than the number of young that are born annually (FRAPNA counts 2013, Figure 15). But they may also be responding to the increased disturbance from activities on the farm. It is possible that once they recognize there is a safe haven in the La Combe valley, they will use it more as a refuge (one herd of 10 individuals was seen for the first time in 2014 Jan).

Other species have increased their numbers and location, for example gentians and orchids. There is a variety of birds, but little evidence that the numbers are increasing despite hunting having been banned now for 10 years. Large boar, roe deer, red squirrels and badgers are more frequently observed, particularly on the improved pastures.

A longer period will be necessary before a significant increase in wildlife species diversity is demonstrated. Non the less, the number of species and their frequency have not declined as a result of the development of the farm, although the location of some of the wild species has change (Figure 16 and Figure 17).

\section{Table 3. Approximate numbers of introduced species.}

Mammals \& birds: 9

Fruit: 15

Vegetables: 35 (plus many different varieties)

Trees: 18

Shrubs: 40

Annuals \& prennials: 60 (plus varieties)

Total: 177

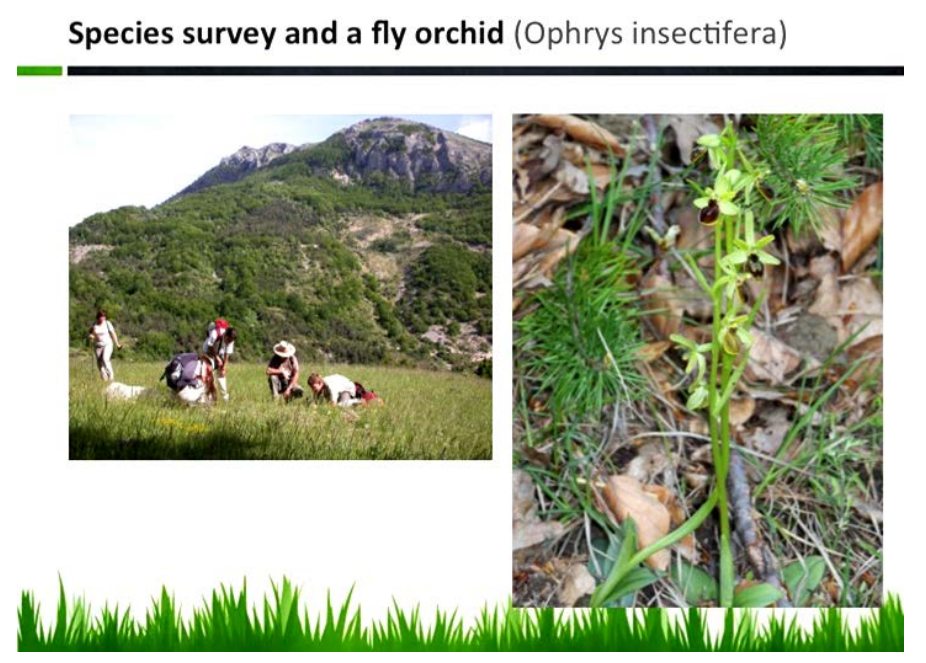

Figure 15. A group of naturalists doing a species survey in 2009 \& a rare orchid. 
Yearly counts decreasing chamois \& increasing gentians

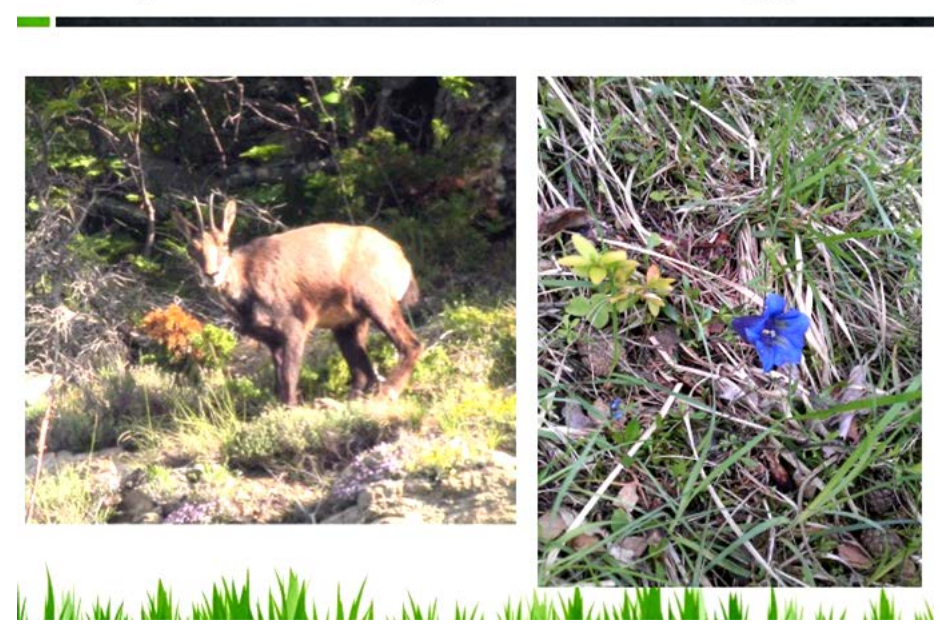

Figure 16. A chamois, one of the threatened mammals in the area, and a gentian, one of the species that has increased in the 10 years of ecological farming.

Species lists for La Combe. 2003-2012.

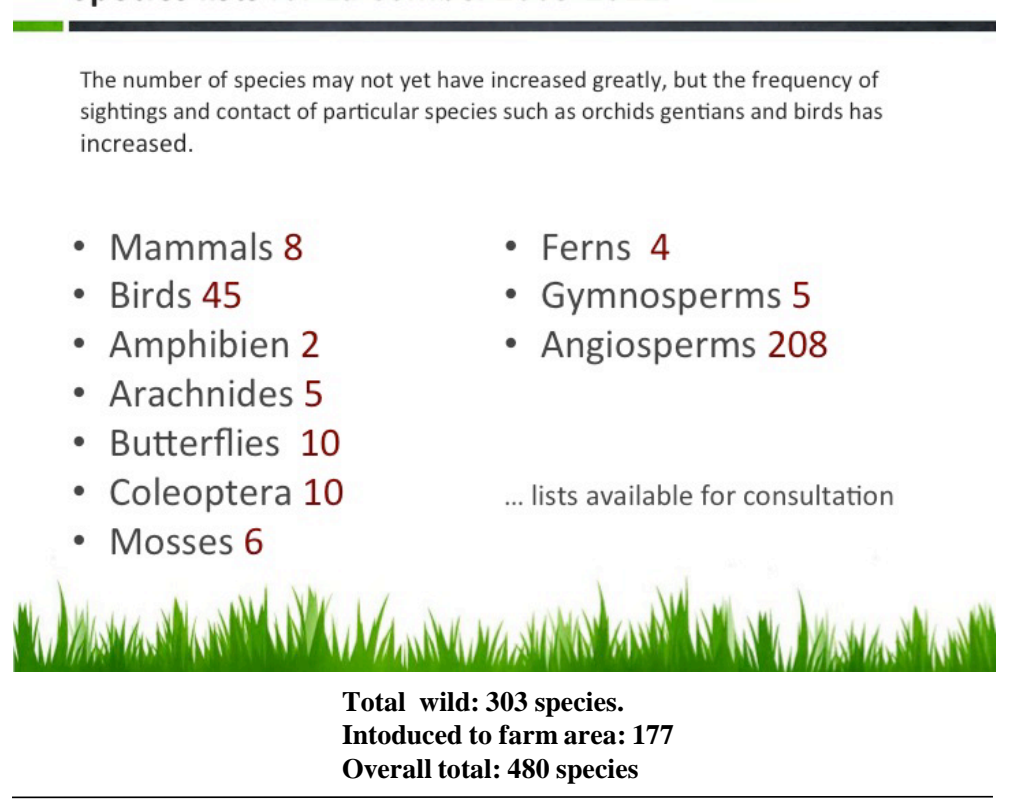

Figure 17. The total number of species, wild and introduced, found on the farm.

There is an increase in the indigenous montane grassland of about 6 ha. This is as a result of clearing and grazing. This has encouraged a greater number of flowering plants in the sward. However the length of grazing time and number and species of animals grazing must continue to be carefully managed to ensure this continue.

\section{4) Economic performance}

The economic performance of European Farms is obscured by the CAP grants. In addition in France there are very generous grants available for young farmers, and headage grants available for livestock. The latter payments were not available to the centre but some PAC grants were, such as for farming in difficult areas.

The economic performance of French small mountain farms, are almost totally depended on the subsidies available. These are in operation in order to encourage and maintain various social and environmental aims (e.g. to keep the rural populations and industries going, for environmental and conservation objectives and to en- 
courage young farmers). As a result, the economic performance is not ruled by either the gross or net production. It is therefore evident that the performance of any farms can be changed rapidly by the subsidies. In effect, their economic performance does not reflect their biological production and efficiency at present.

For the rapid development of the farm, there was a considerable need for capital investment.

Although as many building materials as possible came off the farm (e.g. stones, sand, gravel, wood, fence posts etc.) there was a need for considerable expenditure to improve the human housing. There were no grants available for this.

Another capital outlay was for fencing (approximately $10 \mathrm{~km}$ in order to protect cultivations and for grassland management). The other major capital outlay was on machinery: a tractor, $4 \times 4$ car, livestock \& van transporter, cultivation equipment and hay and silage making machinery. No grants were available for these. As a result, much time was spent seeking out second hand machinery relatively locally. Sharing machinery with local farmers is not a normal occurrence in France unfortunately. Because of the location and small size of the fields, it was not possible to contract out work on the land or harvesting. As a result we were committed to having to buy our own machinery, and repair it ourselves.

To date the capital costs in total have been around E164,000, most of this spent on equipment for human housing. Any hired labour is included, but not the majority which was unpaid resident labour. The economic performance is summarized in Table 4.

These figures do not take into account labour charges because:

a) The employees are not paid in cash, they are paid by having full board and lodging and working part time in exchange. They also are paid by having a life where they have free use of the farm facilities. The resident staff work on the farm full time, and also teach others free of charge for an average of 4 hrs per week.

b) There were approximately 1000 volunteers who helped for more than 1 week during the 10 year period. These volunteers were mostly members of WWOOF (Willing Workers on Organic Farms). Members are of any age, sex, ability, experience but they volunteer to work 5 hrs/day in exchange for their board and lodging, experiencing living on a farm and learn about it. In order to ensure the economics are accurate, it is necessary to estimate their costs which was E10/day (growing of the majority of the food, heating, room, facilities etc.). Therefore to be economic, they must perform work that will allow the farm to earn at least E10/day while they are there to pay for their costs. Approximately 50\% of the volunteers were economic in this sense, although they may also have contributed various social benefits. The majority of the volunteers come from urban backgrounds and have no experience of the practical skills required, although they may be enthusiastic and willing, they are not always efficient. In addition it takes much time, skill and energy to organise them.

This experimental farm has taken a great deal of skill, experience, time, effort, money and motivation in order to construct the infrastructure. However, today, it is evident that it could provide a living for 5 people who have some experience and skills to specialize in different aspects:

a) market gardening, (Figure 18),

b) forestry,

c) land cultivation \& arable crops \& tourism,

d) horse riding \& wildlife.

In this way it could continue to increase its net production and eventually be able to feed more than 20 families while being an important nature reserve \& educational centre for this area.

The most important thing we have learnt on this farm is that the construction of a highly productive ecological farm with a much richer species presence, takes longer than is considered in a mountain area that i) had a history of being heavily grazed a century ago but ii) in the last 70 years has been recolonized by broom, wild rose \& juniper, and the species poor climax beach forest.

Every year the production increases as the soils on the cultivated areas improve. We have completed the 10 year research programme, and are now retiring (although staying on the farm). It is available to others to continue the work, develop it further along the general ideas of Ecological Agriculture and make a living from it.

As an addendum, the development of all these farms and their research have not been financed by anyone or organization other than the farms themselves, and voluntary work. Only the basic agricultural subsidies have been available. Long ago we realized since we do not have salaries that "where there is a will there is always a way", it may take longer, require more motivation, and have many hick-ups, but it Can Always Be Done. It is not for the faint hearted; equally, it may not be for those heavily financed by government as this will be unlikely to be sufficient motivation to keep going when the subsidies run out (Figure 19). 
Table 4. Economic performance of the experimental farm: La Combe.

\begin{tabular}{|c|c|c|c|c|c|c|}
\hline \multirow[t]{2}{*}{ Year } & \multicolumn{2}{|c|}{ Capital expenditure } & \multirow[t]{2}{*}{ Running costs } & \multirow[t]{2}{*}{ Grants } & \multirow[t]{2}{*}{ Sales/livestock/veg/eggs/other } & \multirow[t]{2}{*}{ Profit/loss (excluding capital) } \\
\hline & Houses & Farm & & & & \\
\hline 2004 & 80,800 & 50,000 & 15,849 & 8480 & 2084 & -5284 \\
\hline 2006 & 4175 & 21,991 & 13,984 & 8642 & 8936 & 3594 \\
\hline 2012 & 1122 & 6106 & 14,364 & 10,492 & 15,597 & 11,725 \\
\hline Total & 86,097 & 78,097 & 44,197 & 27,614 & 26,617 & 10,035 \\
\hline
\end{tabular}

\section{A) A glass house for early plants, B) Poultry scavenging}

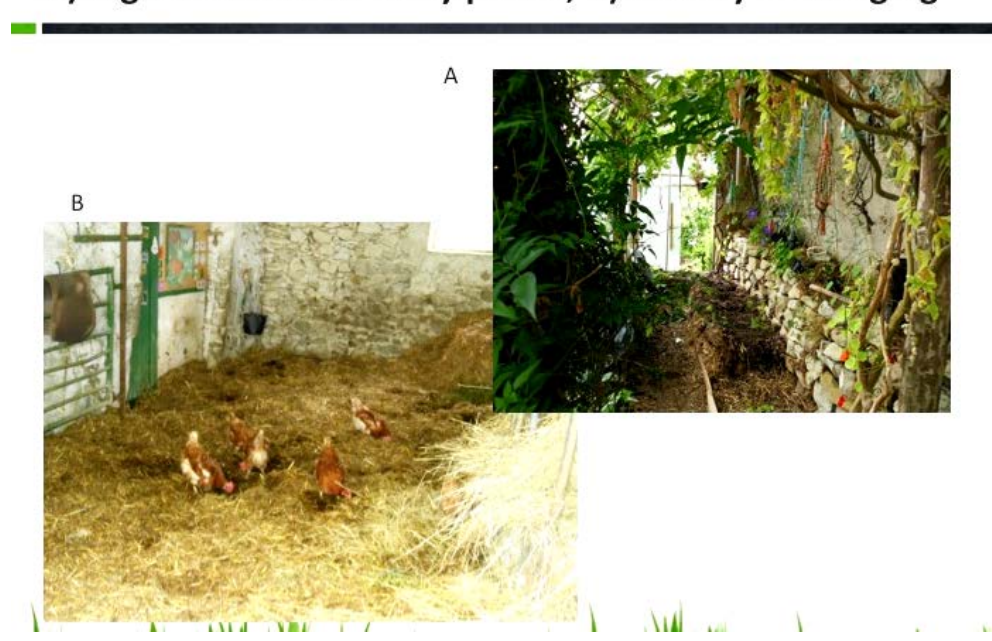

Figure 18. A key feature is the glass house for winter green food, and using the poultry as scavengers saves feed.

Self-sustainability now in A /nutrients ,B) fodder: silage \& hay, c)more wild orchids \& bird indicating some success in wildlife conservation.

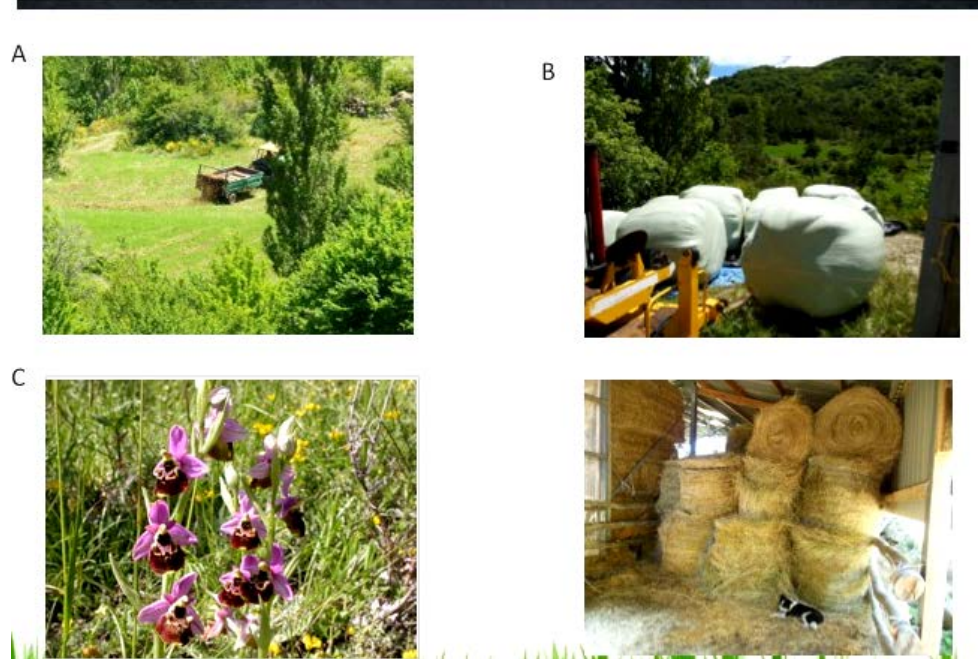

Figure 19. Some successes.

\section{Conclusions}

The performance of this last ecological farm, La Combe which this paper is largely devoted to, there have been considerable difficulties with the climate and lack of fertility. The creation of cultivatable areas, development of soil fertility, how to increase grassland production and the lack of infrastructure have been the major challenges 
for food production. However the 15 hectares of the cultivated farm is increasing its net production annually; another 10 years of similar management will improve it further.

To date the farm has almost achieved its aim of feeding 20 families from its own resources while at the same time the entire farm has been declared a nature reserve and the species diversity and frequency have increased. If many communes in difficult areas, (as well as others), were to develop such self sustaining food production it would help to feed the local populations considerably, even though people may have to change their diets somewhat. The long term advantage being that the diets would be healthier and areas of forest and farms become highly productive but also nature reserves to ensure the survival of future generations of all species.

The most difficult food stuffs to produce biologically efficiently have been shown to be poultry and pig products... the two types of animal products that people are being encouraged to consume more and expanded to feed urban populations. This study has illuminated the environmental and ethical costs of the large scale increase in pig and poultry production. These require large areas for cereal and soya production often produced in different countries at considerable environmental costs. It is clear that pig and poultry production has a greater environmental effect than properly managed, free grazing herbivores.

The importance of indigenous and improved grasslands to feed livestock that do not compete with humans for food is clear. Grazing and browsing herbivores have important roles to play in both feeding human populations and conserving wild areas, despite the fact that when intensively managed they are environmentally expensive. In fact proper management of grazing herbivores can contribute to conservation of the natural world, species diversity, soil fertility and increased net food production anywhere. Here how "proper management" of herbivorous can be achieved in a difficult area has been outlined.

The original suggestion was that this 175 ha farm should be able to feed 30 families when the infra-structure was in place, as well as have forests, montane grasslands, rivers and marsh areas in perpetuity. This was too optimistic within the research period of 10 years but with continual similar management it may be possible to do this as well as to provide work for another 5 people. However, the development of such farms must be emphasised, and it is not for the faint hearted. It is a real need for a great deal of motivation, energy and different skills to achieve these sorts of results.

Self sustainability in energy on farms can be achieved, but care must be taken to ensure the efficient use of appropriate machinery, as well as taking into account the need for resources, energy and transportation in their production. Animal traction and human hand work can be appropriate and efficient, but a careful eye must be kept on their appropriate use if it is to be justified in terms of time and energy efficiency.

The ethical values are that the physical, social, emotional and cognitive needs of all sentient beings, including humans, should be equally considered on the farm [19] [20]. From the point of view of human labour, this must not just involve their economic gains. It also involves payment in life quality and providing facilities on the farm, tuition, food lodging and hobbies which otherwise would have to be paid for. There has been an effort to render such values into economic terms, but it is something that varies greatly between individuals. Idealism, motivation, hard work and a profound wish to contribute have proved to work perhaps better than money payments.

Animal ethics has involved a careful study of their welfare and is of top priority. Herbivores are a necessary addition to increasing wildlife diversity and conservation when appropriately managed. They are cognitively complex beings with physical, social, emotional and cognitive needs and the farmer has an obligation to fulfill these and give the animals a life of quality, despite the fact that they are often slaughtered young. The most difficult animals to keep in any numbers in this system are species whose food competes with humans: pigs and poultry. Keeping them in intensive unites where they suffer all their lives is not an ethical option. It also causes a host of environmental problems. The numbers of all the animals kept must of course be carefully adjusted to the facilities and food produced, in the same way as the number of humans that can be fed must be carefully adjusted in order to ensure that all the existing species can continue to live and have a life of quality.

It is easier to theorize about animal welfare than it is to practice what is preached. Thus over the last 45 years, experiments have been conducted on the various farms in order to work out ways in which all species can have a life of quality, and how to measure this, while remaining within the tenets of Ecological Agriculture. The ultimate baseline is that all the sentient beings should be able to make choices and decisions, acquire information both ecologically and socially, have mental stimulation and have all their needs met for the majority of their lives [21]. Then it can be considered that they have a life of quality. To do this at this stage of our knowledge concerning different species cognition it is necessary to consider that because they have evolved to live the way they do, they should be able at least at some point in their lives to be able "to perform all the behaviour within 
their repertoires that does not cause suffering to others". If behaviours need to be restricted (e.g. uncontrolled sexual activity), arguments must be made that the quality of life of that individual will be improved if he suffers such a restriction (this can be argued sometimes for castrating). All species must also have access to appropriate nutrition, medical care, shelter and exercise [19] [20].

Aesthetic values change with cultures, history and humans daily experiences [22]. However there are baselines of what is "liked", "pleasant" and "beautiful" by humans as well as other species. One of the most clear baselines is that the majority of all mammals (at least) find a diversified and changing environment pleasanter than one that is always constant. The aim on the farm has been to model the gardens and cultivated areas appearance on that of the wild world that surrounds them, although this involves the introduction of new and different species. Chance, rather than formal design has often been the guiding motive: seeds and plants were planted and the micro-climates used wherever possible, but their survival as in the wild, is controlled often by chance.

It has become increasingly clear that in order to encourage humans at least, to become interested in the farm and what it is achieving, it must be aesthetically pleasing or they will not want to understand more. This has involved very careful debates concerning where and what trees to plant, hedges to cut and lay, fences to build as well as careful design of any changes to the buildings and having healthy, beautiful, friendly animals around among many other things.

This type of agriculture even in marginal areas has been shown to be able to have some advantages in terms of net production, that is it is able to feed a greater number of people, while also benefiting wildlife conservation and species diversity. Consequently it is a useful approach for the future to ensure efficient food production for the growing human populations, while retaining the wildlife on farmed land.

The economic performance has warranted large capital investment. This would not have been needed if more time had been available for the development of the farm. However, after 10 years it is now economically viable. The rewards of farming in this way are not just financial. They include recognizing that food security, freedoms to make choices, animal and environmental ethics and aesthetic values are important. Such a farming system will allow individuals to work to achieve a life of quality with less material gains. All of these benefits can be converted to economic benefits, but non material gains are difficult to quantify partly because there are large differences between individuals in how they are valued. It must be born in mind that even where people lack food and shelter, maximizing economic gain, with all its concomitant problems, is not a universal solution (e.g. [23] \& personal interviews with women farmers in Kenya, Zimbabwe, Malawi). If there is no food, however rich you are, you will starve!

\section{References}

[1] Kiley-Worthington, M. (1993) Ecological Agriculture, Food First Farming. Souvenir Press, London.

[2] http://www.worldometers.info/world-population/

[3] Dumont, R. and Rosier, B. (1969) The Hungry Future. Methuen, London.

[4] Carson, R. (1965) Silent Spring. Houghton Mifflin, Boston.

[5] Harrison, R. (1968) Animal Machines. Lyle Stuart, London.

[6] Kiley-Worthington, M. (1980) Problems of Modern Agriculture. Food Policy, 5, 208-215. http://dx.doi.org/10.1016/0306-9192(80)90129-3

[7] Koept, H., Patterson, B.D. and Schaumann, W. (1976) Biodynamic Agriculture. Anthroposophic Press, New York.

[8] Balfour, E.B. (1975) The Living Soil and the Haughley Experiment. Faber \& Faber, London.

[9] Kiley-Worthington, M. (1981) Ecological Agriculture. What It Is and How It Works. Agriculture \& Environment, 6, 349-381. http://dx.doi.org/10.1016/0304-1131(81)90039-4

[10] http://www.agmrc.org/markets industries/food/organic-food-trends/

[11] Woodward, L. (2013) Land Health. Proceedings of International Colloquium on the Future of Agriculture, Eco-EthoRecherche Centre, La Drome.

[12] (1974) Proceedings of the British Ecological Society Summer Meeting, Aberystwyth, Wales.

[13] http://en.wikipedia.org/wiki/Aid

[14] The Drumghigha Project (1987) An Ecological Farm in a Marginal Area. In: Allen, P. and van Drusenm, D., Eds., Global Perspectives on Agroecology \& Sustaiaable Agricultural Systems, IFOAM, Conference Agroecology, Univer- 
sity of California, Santa Cruz, 273-283.

[15] Naess, A. and Haukeland, P.I. (2002) Life’s Philosophy: Reason and Feeling in a Deeper World.

[16] http://wwf.panda.org/about_our_earth/biodiversity/biodiversity/

[17] Kiley-Worthington, M. and Rendle, C.C. (1984) Ecological Agriculture. A Case Study of an Ecological Farm in the South of England. Biological Agriculture \& Horticulture, 2, 101-133. http://dx.doi.org/10.1080/01448765.1984.9754423

[18] Savoury, A. (1991) Holistic Resource Management. Glimour Publishing, Avondale.

[19] Clark, S. (1976) The Moral Status of Animals. Oxford University Press, Oxford.

[20] Dawkins, M.S. (1993) Through Our Eyes Only? The Search for Animal Consciousness. W H Freeman, Oxford.

[21] Kiley-Worthington, M. (2000) Equine and Elephant Epistemology. M.Phil (Philosophy), Lancaster University, Lancaster.

[22] Cooper, D. (1992) A Companion to Aesthetics. Blackwell, Oxford.

[23] Hanon, J., Manjengwe, J. and Smart, T. (2013) Zimbabwe Takes back It’s Land. Kumarian Press, Virginia. 
Scientific Research Publishing (SCIRP) is one of the largest Open Access journal publishers. It is currently publishing more than 200 open access, online, peer-reviewed journals covering a wide range of academic disciplines. SCIRP serves the worldwide academic communities and contributes to the progress and application of science with its publication.

Other selected journals from SCIRP are listed as below. Submit your manuscript to us via either submit@scirp.org or Online Submission Portal.
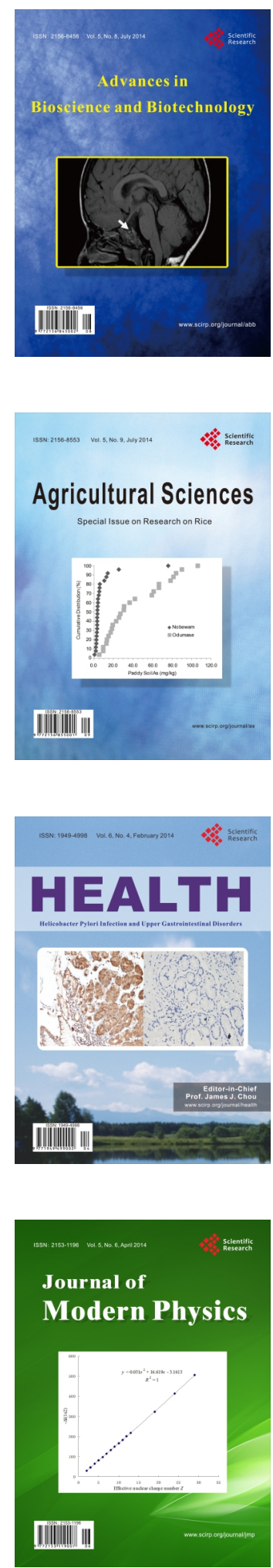
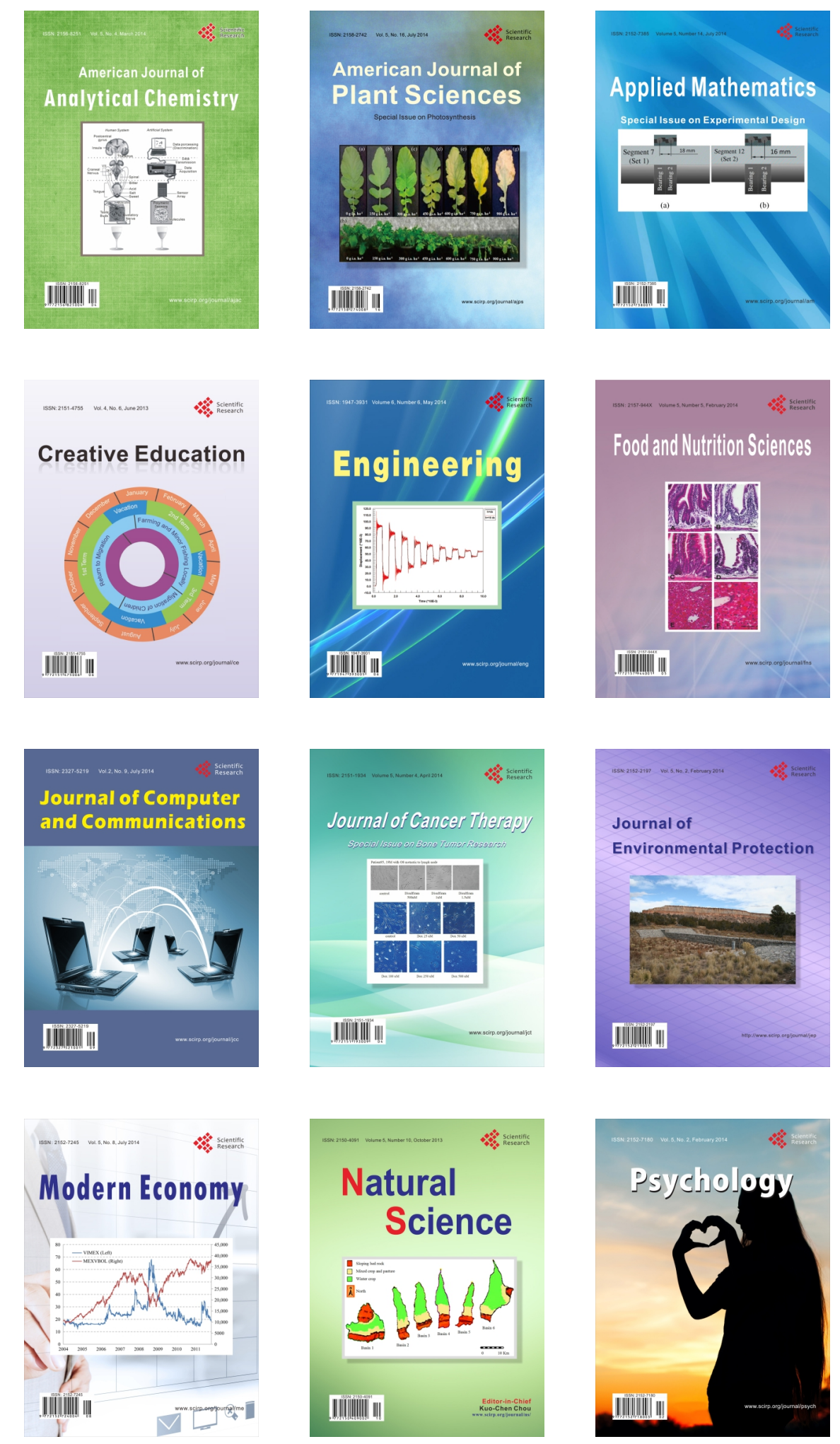